\title{
The birth and re-birth of respiratory medicine-notes from the British Thoracic Society Winter Meeting 2006
}

\author{
J K Quint, R Baghai-Ravary
}

$\mathrm{T}$ he annual Winter British Thoracic Society (BTS) meeting in December 2006 provided us with yet another exciting forum for both scientists and clinicians to share advances in respiratory medicine. The meeting consisted of inspiring, novel and interesting work, presented by students and non-clinicians, as well as world renowned respiratory physicians. Professor Stephen Holgate, in his address as President of the BTS entitled "The birth and re-birth of respiratory medicine", spoke of changes and shared his visions for the future. Dr Alex Richter and Dr Clare Sander deserve congratulations for their success in the Young Investigator Prizes. In this review we highlight some of the important spoken and abstract sessions from the meeting.

\section{COPD}

Chronic obstructive pulmonary disease (COPD) was well represented at the meeting this year, with a stimulating symposium focusing on the science and impact of exacerbations. Spoken sessions on a novel in vivo model of human rhinovirus infection ${ }^{1}$ and application of real-time quantitative polymerase chain reaction for the detection of bacteria $^{2}$ opened platforms for improved understanding of the infectious mechanisms of exacerbations. There was evidence to suggest that prolonged exacerbation in smokers may be related to impaired neutrophil activation. ${ }^{3}$ Smoking cannabis was related to greater airflow obstruction than cigarettes, ${ }^{4}$ re-enforcing the need to address all smoking cessation.

The consequences of depression in COPD, in particular the associations with mental and general fatigue, ${ }^{5}$ relation to reduced time spent outdoors, healthrelated quality of life $^{6}$ and failure to complete pulmonary rehabilitation, ${ }^{7}$ were discussed in several sessions. Randomised controlled trials are needed to investigate reports of benefit from pulmonary rehabilitation initiated during admission for acute exacerbation $^{8}$ and in maintenance of weekly supervised exercise sessions.9 An assessment of the national availability, need, cost-effectiveness and outcome of pulmonary rehabilitation ${ }^{10}{ }^{11}$ may be facilitated by a national register.

\section{BASIC SCIENCE}

The importance of basic science was evident throughout the BTS meeting. Symposia on biomarkers in respiratory diseases looked at blood, induced sputum and exhaled nitric oxide as potential sources, rich in markers of respiratory disease but not yet fulfilling their potential. Metal ions such as zinc were proposed as potential biomarkers in suppurative lung disease. ${ }^{12}$

Application of basic science in lung transplantation covered topics ranging from acute rejection ${ }^{13}{ }^{14}$ to mechanisms of immunosuppression ${ }^{15}$ and the importance of pulmonary vasculature in situations of infection. ${ }^{16}$

The role of transforming growth factorbeta (TGF- $\beta$ ) in lung disease was discussed in a number of sessions. In pulmonary fibrosis, activation of proteinase activated receptor- 1 increased the release of TGF- $\beta$ through thrombospondin- $1 .{ }^{17}$ Murine models of pulmonary hypertension showed the importance of TGF- $\beta$ signalling through downregulation of the bone morphogenic protein type II receptor, ${ }^{18}$ and a pathway for regulating vascular endothelial growth factor (VEGF) in pulmonary artery smooth muscle cells was demonstrated. ${ }^{19}$

\section{ASTHMA}

An abundance of basic science sessions gave thorough insight into the inflammatory pathways and cellular responses in asthma. This included mechanisms of respiratory syncytial virus infection through interactions with human monocyte-derived dendritic cells, ${ }^{20}$ the role of Toll-like receptors in airway smooth muscle and epithelial cells, ${ }^{21}$ and mechanisms of neutrophil activation in airways. ${ }^{22}$ Asthmatic bronchoalveolar lavage factors were shown to stimulate fibroblastic collagen III, ${ }^{23}$ suggesting a potential means for modulating airway remodelling. Evidence of increased IL-13 expression by smooth muscle mast cells in eosinophilic asthma compared with noneosinophilic asthma ${ }^{24}$ may explain differences in corticosteroid responsiveness.

\section{TUBERCULOSIS AND PULMONARY INFECTION}

The Snell memorial lecture, delivered by Professor Ormerod on the current treatment of tuberculosis (TB), provided a fantastic background to many of the posters displayed on diagnostic methods and treatment of TB. Spoken sessions focused on the epidemiology of TB and highlighted issues ranging from the increase in TB in England and Wales ${ }^{25}$ in recent years to the difficulty in accessing treatment for $\mathrm{TB}$ in rural Zimbabwe. ${ }^{26}$ Outcomes of the implementation on the NICE guidelines on immigration screening $^{27}$ were discussed, together with the importance of screening patients from areas of very high prevalence.

Spoken sessions on pulmonary infection indicated that C-reactive protein (CRP) is related to severity of community acquired pneumonia $(\mathrm{CAP})^{28}$ and can exclude CAP. However, a large national survey showed room for significant improvement in availability of sputum Gram staining and urinary antigen testing, particularly out-of-hours. ${ }^{29}$ Inpatient studies showed that bacterial pneumonia and fluid overload were the commonest causes of respiratory complications in haematological inpatients. ${ }^{30}$ Interestingly, visualisation of the bronchial tree was rarely helpful for infection in a broad range of diseases, ${ }^{31}$ suggesting that sputum induction should be considered more often.

\section{INTERSTITIAL LUNG DISEASE AND ACUTE LUNG INJURY}

The underlying mechanisms of acute lung injury (ALI) were unravelled at different levels of the inflammatory cascade. Pulmonary fibrosis is thought to occur early in ALI/acute respiratory distress syndrome (ARDS), indicating that research concentrating on the early fibrotic response may be central in reshaping this disease. ${ }^{32}$ Cellular studies showed that VEGF isoforms have differential effects on primary human lung microvascular endothelial cell proliferation ${ }^{33}$ while, in mechanical stretch-related ALI, mitochondrial reactive oxygen species played a key role. ${ }^{34}$ After cardiopulmonary bypass surgery the delay in apoptosis and development of severe inflammatory response syndrome may be due to the induction of neutrophil heme oxygenase$1 .^{35}$ 
In systemic sclerosis, anti-topoisomerae antibody rather than extent of skin disease was shown to predict pulmonary fibrosis. ${ }^{36}$ The coagulation cascade has been shown to be increasingly important in fibrotic lung disease and local production of factor $X$ presented a potential target for blockade. ${ }^{37}$

\section{PULMONARY HYPERTENSION AND OTHER PULMONARY VASCULAR DISORDERS}

Basic science featured strongly in the spoken sessions on pulmonary hypertension. The importance of the interaction between Smad and activated protein kinase signalling was shown to play an important part in familial pulmonary arterial hypertension..$^{38}$ There were therapeutic implications for the role of prepro -ET-l gene activation in human pulmonary arterial smooth cells, ${ }^{39}$ and selective inhibition of the signalling pathway in hypoxia-induced pulmonary adventitial fibroblast proliferation by fluvastatin. ${ }^{40}$

One study suggested that pulmonary arteriovenous malformations (PAVM) are commonly complicated by ischaemic stroke and brain abscesses. ${ }^{41}$ In these patients PAVM embolisation may be a therapeutic option. ${ }^{42}$

\section{PAEDIATRIC LUNG DISEASE}

The recognition of the importance of paediatric lung disease within the setting of the BTS Winter Meeting was apparent in the number of sessions devoted to this subject. Presentations ranged from topics focused on pneumonia and empyema ${ }^{43}$ to cystic fibrosis ${ }^{44}$ and pulmonary hypertension related to congenital diaphragmatic hernia. ${ }^{45}$

With the increase in incidence of obesity, physical activity in children was increasingly under scrutiny, even in asthma. ${ }^{46}$ There was even acknowledgement that involvement of paediatric staff is important in parental smoking cessation if we are to improve the environment in which children grow up. ${ }^{47}$

\section{PLEURAL DISEASE}

Availability of image-guided pleural biopsy remains a difficult issue in many hospitals, and two studies showed evidence that blind pleural biopsy can be an effective alternative. ${ }^{48}{ }^{49}$ Poster presentations showed most chest specialists are interested in being trained to perform bedside transthoracic ultrasonography, ${ }^{50}$ and the procedure is easily learned. ${ }^{51}$ Reassuringly, there was less pain with guidewire drain insertion than with blunt dissection. ${ }^{52}$

\section{MALIGNANT DISEASE}

Time was devoted to presentations and posters on mesothelioma and lung cancer throughout the conference. Topics ranged from methods to improve diagnosis, to novel treatments, and survival figures. There was an abstract on early results from data collected for the national LUCADA database, amalgamating 10920 cases of lung cancer diagnosed in England in 2005..$^{33}$

Suggestions were made for improving the diagnostic yield from bronchoscopy. The use of newer videobronchoscopes, even without autofluorescence, were found in one hospital to be superior to the use of older scopes in detecting lung cancers. $^{54}$ Another presentation highlighted the benefit of blind bronchial brushings, biopsies, lavage and fine needle aspiration in patients with lesions visible on chest radiography but not on bronchoscopy. ${ }^{55}$ There was a poster on the use of endobronchial ultrasound to guide transbronchial needle aspiration in allowing a more rapid and accurate diagnosis. ${ }^{56}$ The incorporation of transbronchial needle aspiration into an integrated care pathway in two hospitals reduced the rate of mediastinoscopies by about $49 \% .^{57}$

Significant delay between detection of unilateral effusion and diagnosis of mesothelioma ${ }^{58}$ may be tackled through improved referral pathways. In patients over the age of 65 , decortication by videoassisted thoracic surgery may confer better survival than pleuropneumonectomy $^{59}$ and deserves further investigation. One group reported a decrease in the risk of death now compared with previously in patients with a diagnosis of non-small cell lung cancer. ${ }^{60}$ Another group found shorter survival rates in patients undergoing surgical resection of lung cancer than in other countries, suggesting that survival in the UK is not as good as elsewhere. ${ }^{61}$

\section{SLEEP DISORDERED BREATHING} AND OBSTRUCTIVE SLEEP APNOEA

The increasingly important topic of obesity hypoventilation syndrome (OHS) was highlighted. The prevalence of OHS in the catchment area of one UK sleep clinic was found to be above $16 \%{ }^{62}$ Both obstructive sleep apnoea (OSA) and OHS were found to be very common in patients undergoing assessment for bariatric surgery, with Epworth sleep score and symptoms of tiredness reported by patients being poor predictors of diagnosis. ${ }^{63}$

The increased recognition that OSA accompanies other systemic diseases was also discussed. One presentation highlighted the fact that patients with OSA tend to be more obese, more insulin resistant and have higher systolic blood pressures than patients without OSA, thus having higher cardiovascular risks.
In these patients lower thresholds for statin use may be more appropriate. ${ }^{64}$ Another presentation discussed the finding that continuous positive airway pressure does not improve glycaemic control in patients with insulin resistance or type 2 diabetes and OSA. ${ }^{65}$

\section{OXYGEN AND VENTILATION}

Support for the new home oxygen guidelines introduced in February 2006 was reinforced in a poster indicating that patients' oxygen requirements change within 6 weeks of discharge from hospital, hence the importance of follow-up assessment at this time. ${ }^{66}$ Another poster recommended overnight stay for assessment of long-term oxygen treatment to prevent the development of iatrogenic hypercapnia. ${ }^{67}$ However, the use of oxygen acutely was not reported to be without concern, with several posters highlighting the important issue of its overuse in patients with $\mathrm{COPD}^{68}$ and suggestions for prevention of the use of high flow oxygen in the ambulance setting by the administration of oxygen alert cards. ${ }^{69}$

The role of non-invasive ventilation (NIV) was discussed in the context of a variety of topics. The use of NIV or intubation early in type 2 respiratory failure in patients with COPD was highlighted as a method for reducing inhospital mortality. ${ }^{70}$ In one poster presentation, delays in starting NIV were found in $25 \%$ of cases, suggesting the need for target times to reduce the risk of death, as with other diseases. ${ }^{71}$ There was also a presentation on the uptake of home NIV, stressing that patients with OHS tolerate it best, whereas after thoracoplasty patients have a much lower probability of continuation. ${ }^{72}$ It was also tolerated well in patients with COPD. ${ }^{73}$

\section{AND LAST, BUT NOT LEAST ...}

Thorax celebrated its 60th birthday in 2006 with a special December edition and a lunchtime meeting on the last day of the BTS Winter Meeting. This celebration included presentations by Dr Fiona Godlee, Editor of the BMJ, and Professor Anthony Seaton, Editor of Thorax from 1977 to 1982. They both gave very interesting insights into how Thorax has developed over the years and how the work of the editors has changed since the start of the journal in 1946. No doubt Thorax will continue to evolve over the next 60 years and we wish the journal every success.

\section{ACKNOWLEDGEMENTS}

Thanks to Professor Stephen Holgate for allowing the use of the title of his lecture for the title of this piece of work. 
Thorax 2007;62:382-385

doi: $10.1136 /$ thx.2007.080325

\section{Authors' affiliations}

J K Quint, R Baghai-Ravary, Academic Unit of

Respiratory Medicine, University College

London, London, UK

Correspondence to: Dr J K Quint, Department of Academic Respiratory Medicine, Royal Free Hospital, Rowland Hill Street, London NW3 2QG, UK; i.quint@medsch.ucl.ac.uk

Funding: None.

Competing interests: None.

\section{REFERENCES}

1 Mallia P, Message S, Contoli M, et al. An experimental model of virus induced chronic obstructive pulmonary disease exacerbation. Thorax 2006:61 (Suppl II):S76.

2 Perera W, Ling C, McHugh T, et al. Quantitative detection of $S$ pneumoniae, $H$ influenzae and $M$ catarrhalis in sputum samples from chronic obstructive pulmonary disease by real-time polymerase chain reaction. Thorax 2006;61(Suppl II):S77.

3 Bourne S, Seumois G, Pandaurangan V, et al. Differences between smokers and ex-smokers in severity and mechanisms of infectious exacerbations. Thorax 2006:61(Suppl II):P94.

4 Aldington S, Williams $M$, Nowitz $M$, et al. The effects of cannabis on pulmonary structure, function and symptoms. Thorax 2006;61 (Suppl II):S32.

5 Lewko A, Canavan J, Spencer M, et al. An evaluation of relationship between fatigue and depression in patients with chronic obstructive pulmonary disease. Thorax 2006;61(Suppl II):P90.

6 Quint JK, Baghai-Ravary R, Donaldson GC, et al. Outdoor activity and depression in chronic obstructive pulmonary disease. Thorax 2006;61(Suppl II):P82.

7 Jolley CJ, Backley J, Russell A. Factors affecting completion of pulmonary rehabilitation programmes in south east London. Thorax 2006;61(Supp II):S101.

8 Bond JC, Prime H, Vincent EE. In-patient pulmonary rehabilitation during acute exacerbation of chronic obstructive pulmonary disease: immediate effects on health status and exercise capacity. Thorax 2006:61(Suppl II):S98

9 Singh SJ, on behalf of British Lung Foundation Lung Exercise Pilot Project team. The British Lung Foundation lung exercise pilot project: Is it effective? Thorax 2006:61(Suppl II):S102.

10 Waterhouse JC, Walsh J, Revill S, et al. Benchmarking pulmonary rehabilitation: should there be some standardisation? Thorax 2006;61/Suppl II):P39.

11 Oluboyede Y, Waterhouse JC, Walters S, et al. Best buy for pulmonary rehabilitation: Comparison of community and hospital provision. A report of the cohort study of pulmonary rehabilitation. Thorax 2006;61(Suppl II):P40

12 Gray RD, Duncan A, Imrie M, et al. Sputum metal ions are biomarkers for suppurative and inflammatory lung disease. Thorax 2006;61(Suppl II):S121.

13 Stovold R, Forrest IA, Murphy DM, et al. Evidence of increased gastric aspiration in acute lung allograft rejection. Thorax 2006;61(Suppl II):S6.

14 Fildes JE, Walker AH, Tunstall K, et al. Is there a role for natural killer cells following lung transplantation? Thorax 2006;61(Suppl II):S9.

15 Anderson R, Hiemstra PS, Verhoosel R, et al. The effect of immunosuppressants on secretory leucoproeinase inhibitor production by lung epithelium in the presence of transforming growth factor-beta. Thorax 2006;61(Suppl II):S7.

16 Rao VP, Kim HK, Odell J, et al. Pulmonary vascular reactivity in infected single lung allografts. Thorax 2006;61(Suppl II):S11.

17 Wilson NA, Worku ML, Moffatt JD, et al. Activation of proteinase activated receptor-1 on mesothelial cells induces activation of transforming growth factor-beta via upregulation of thrombospondin-1. Thorax 2006;61(Suppl II):S25.
18 Long L, Crosby A, Southwood M, et al. Characterisation of bone morphogenetic protein and TGF- $\beta$ signalling pathways in monocrotaline and hypoxia induced pulmonary arterial hypertension in the rat. Thorax 2006;61(Suppl II):S23.

19 Clifford R, Deacon K, Corbett L, et al. Transformin growth factor $\beta 1$ regulation of vascular endothelial growth factor in pulmonary artery smooth muscle cells. Thorax 2006;61(Suppl II):S55.

20 Hobson L, Coleman CM, Plant K, et al. Pro and anti-apoptotic actions of respiratory syncytial virus on productively infected dendritic cells. Thorax 2006;61(Suppl II):P56

21 Parker LC, Jones EC, Morris GE, et al. The induction of antiviral responses in human airway. Thorax 2006;61(Suppl II):S20.

22 Uddin M. Seumois G, Lau LC. Activation of neutrophils by the repairing bronchial epithelium are regulated via P13-kinase/AKT/protein kinase C delta-mediated signals. Thorax 2006;61(Suppl III):S21.

23 Sanders PN, Buckley MG, Lau LCK. Primary airway fibroblasts in the understanding of asthma: extracellular matrix gene expression. Thorax 2006;61(Suppl II):S18.

24 Saha SK, Berry M, Neale N, et al. Interleukin-13 expression by mast cells in the airway smooth muscle bundle in eosinophilic but not non-eosinophilic asthma. Thorax, 2006;61, (Suppl II):S19.

25 Kruijshaar ME, Abubakar I, Crofts J, et al. Substantia increase in tuberculosis incidence in England and Wales in 2005. Thorax 2006;61(Suppl II):S1

26 Barker RD, Millard FJC, Graham VAL, et al. The incidence of tuberculosis in relation to distance from a diagnostic and treatment centre. A study in rural Zimbabwe. Thorax 2006;61(Suppl II):S4.

27 Datta B, Watson JP. Outcomes of new immigrant screening for tuberculosis: implications for implementation of NICE guidelines. Thorax 2006;61(Suppl II):S5

28 Chalmers J, Singanayagam A, Hill A. C-reactive protein is an independent marker predicting severity in community acquired pneumonia. Thorax 2006;61(Suppl II):S67

29 Roberts ME, Macfarlane JT, George RC, et al. Microbiology investigations in community acquired pneumonia: what is available from England and Wales laboratories? Thorax 2006;61 (Suppl II):S64.

30 Cooper SJ, Brown JS. A 12 month review of respiratory complications of haematology inpatients. Thorax 2006;61(Suppl II):P134.

31 Sage EK, MacDonald A, Twort CHC. Does visualisation of the bronchial tree add value when investigating possible lung infection? Thorax 2006;61(Suppl II):P135

32 Howell DJC, Falzon $M$, Bilbe $N$, et al. Pulmonary fibrosis is an early feature of acute lung injury/ acute respiratory distress syndrome. Thorax 2006;61(Suppl II):S143.

33 Varet J, Bates D, Harper S, et al. Differential effects of vascular endothelial growth factor isoforms on primary human lung microvascular endothelial cell proliferation. Thorax 2006;61(Suppl II):S141.

34 Pinhu L, Griffiths JD. Mitochondrial reactive oxygen species are required for mechanical strain-induced interleukin-8 production by lung epithelial cells. Thorax 2006;61 (Suppl II):S146.

35 Melly DD, Lagan L, Quinlan GJ, et al. Heme oxygenase- 1 is induced in human neutrophils following surgery requiring cardiopulmonary bypass. Thorax 2006;61(Suppl II):S142.

36 Hoyles RK, Black CM, du Bois RM, et al. Autoantibody profile rather than extent of skin disease predicts severity of pulmonary fibrosis in systemic sclerosis. Thorax 2006;61(Suppl II):S103.

37 Scotton CJ, Krupiczojk M, Johns RH, et al. The coagulation cascade in fibrotic lung disease progression: local expression of factor $\mathrm{X}$ is increased in the injured and fibrotic lung. Thorax 2006;61(Suppl II):S104.

38 Yang J, Rudarakanchana N, Trembath RC, et al. Interaction between SMAD and mitogen-activated protein kinase signalling in familial pulmonary arterial hypertension. Thorax 2006;61(Suppl II):S52.

39 Wort SJ, MaMaster S, Mitchell A, et al. Acetylation of histone $\mathrm{H} 4$ at NF-kappaB sites on pre-pro ET-1 promoter is involved in synergistic synthesis of ETin human pulmonary artery smooth muscle cells treated with TNF-alpha and IFN-gamma. Thorax 2006;61 (Suppl II):S53

40 Carlin CM, Peacock AJ, welsh DJ. Fluvastatin selectively inhibits hypoxic proliferation and activation of P38 MAP kinase in pulmonary artery fibroblasts: implications for pulmonary hypertension treatment. Thorax 2006;61(Suppl II):S54.

41 Shovlin $\mathrm{CL}$, Benjamin AR, Ramadan $\mathrm{H}$, et al Ischaemic stroke and brain abscess due to pulmonary arteriovenous malformations. Thorax 2006;61(Suppl II):P22.

42 Shovlin CL, Davies RJ, Gibbs JSR, et al. Pulmonary arterial pressure, pulmonary arteriovenous malformations (PAVMs), and PAVM embolisation. Thorax 2006;61(Suppl II):P23.

43 Roxburgh CSD, Youngson GG, Turner SW. Trends in pneumonia and empyema in Scottish children in the past 25 years. Thorax 2006;61(Suppl II):S41.

44 Adams A, Mackensie R, Olden C, et al. Do estimations of habitual activity in children with cystic fibrosis predict aerobic fitness? Thorax 2006;61 (Suppl II):S42.

45 Corbett HJ, Connell MG, Fernig DG, et al. SMAD signalling and MAP kinase activity in experimental congenital diaphragmatic hernia. Thorax 2006;61(Suppl II):S43.

46 Smyth A, McPherson A, MacDonald I, et al. Body mass index, physical activity, and beliefs about exercise in children with asthma. Thorax 2006;61(Suppl II):S71

47 Pillarisetti N, Boit P, Clayton S, et al. Knowledge of quit smoking services by hospital paediatric staff. Thorax 2006;61(Suppl II):S63

48 Nadama R, Pasteur M. Are blind percutaneous pleural biopsies still useful in diagnosis of suspected malignant pleural effusion? Thorax 2006;61(Suppl II):P187

49 Guhan AR, Walker PT, Leen GS, et al. Ninety two per cent of current respiratory specialist registrars think that training in chest ultrasound examination for pleural disease should be included in their training curriculum: result of a national web-based questionnaire survey on the practice of chest ultrasound examination in the UK. Thorax 2006:61(Suppl II):P188.

50 Guhan AR, Walker PT, Leen GS, et al. Survey of the practice of chest ultrasound examination (for pleural effusions) among chest physician in the UK Thorax 2006;61(Suppl II):P189.

51 Faruqi S, Sundar R, Kastelik JA, et al. Bedside transthoracic ultrasonography by respiratory physicians. Thorax 2006;61(Suppl II):S128.

52 Rahman NM, Maskell NA, Hedley EL, et al. Which aspect of chest drainage causes most pain? Thorax 2006:61(Suppl II):P191.

53 Chanarin N, Stanley R, Peake MD. National lung cancer audit (LUCADA): highlights from the first annual report. Thorax 2006;61(Suppl II):S89.

54 Cetti E, Nicholson AG, Singh S, et al. A comparison of autofluorescence bronchoscopy and videobronchoscopy for the detection of pre-invasive lesions in patients with possible lung cancer. Thorax 2006;61(Suppl II):S37.

55 Sundararajan L, Youzguin A, Lees D, et al. Improving the diagnostic yield from bronchoscopy where there is no visible endobronchial lesion. Thorax 2006;61(Suppl II):S38.

56 Munavvar M, Gupta V, Patel V, et al. Utility of endobronchial ultrasound (EBUS): a comparative study between conventional transbronchial nodal aspiration (TBNA) and EBUS guided TBNA. Thorax 2006;61(Suppl II):P139.

57 Singh S, Lai D, Davies G, et al. The role of transbronchial needle aspiration in an integrated care pathway for assessment of patients with suspected lung cancer. Thorax 2006;61(Suppl II):S35.

58 Barnes D, Entwisle J. A one year retrospective review of the radiological investigations of confirmed mesothelioma patients in a tertiary referral centre. Thorax 2006;61(Suppl II):P185.

59 Nakas A, Martin-Ucar E, Barlow A, et al. The extent of surgery for malignant mesothelioma in patients over age of 65: a therapeutic dilemma? Thorax 2006;61(Suppl II):S126

60 Chiu G, Muza R, Patel S, et al. Survival rates for 705 histologically proven non-small cell lung cancer diagnosed between November 1997 and December 2004 and managed by a multidisciplinary team. Thorax 2006;61(Suppl II):S92. 
61 Quint JK, Eraut D, Ansari S, et al. Survival following surgical resection of lung cancer: a district experience. Thorax 2006:61(Suppl II):P13.

62 Bright J, Sharman M, Turkington PM. Prevalence and clinical characteristics of obesity hypoventilation syndrome presenting to a UK sleep clinic. Thorax 2006;61(Suppl II):P65.

63 Pepperell JCT, Van Rensburg G, Welborn R, et al. High prevalence of sleep apnoea and nocturnal hypoventilation in patients assessed for bariatric sugery. Thorax 2006;61(Suppl II):S155.

64 Horwood F, Gruber A, Sithole J, et al.

Cardiovascular risk assessment in patients with obstructive sleep apnoea: clinical utility of the joint British societies cardiac risk assessor program. Thorax 2006;61(Suppl II):S154.

65 West SD, Nicoll DJ, Wallace TM, et al. The effect of CPAP on insulin resistance and $\mathrm{HBA} 1 \mathrm{C}$ in people with obstructive sleep apnoea and type 2 diabetes: a randomised controlled trial. Thorax 2006;61(Suppl II):S152.

66 Creasey J, Mukheriee D, Yung B, et al. The outcome of a review of oxygen orders following patients' attendance at an oxygen clinic. Thorax 2006;61(Suppl II):P167

67 Khashkhusha R, Sutcliffe I. Do we need to admit patients overnight for long term oxygen therapy assessment? Thorax 2006;61(Suppl II):P176.

68 Barker RD, Smith L, Fenton J, et al. High flow oxygen as a risk factor for death in patients admitted to hospital with acute exacerbations of chronic obstructive pulmonary disease. Thorax 2006;61(Suppl II):P169.

69 Tooley C, Ellis D, Greggs D, et al. Too much of a good thing? Oxygen alert cards are helpful for chronic obstructive pulmonary disease patients at risk of oxygen toxicity. Thorax 2006;61(Suppl II):P171.

70 Snelson C, Hawthorne G. Audit of chronic obstructive pulmonary disease patients with acute type II respiratory failure: are we giving them a chance? Thorax 2006;61(Suppl II):S148.

71 Sivalingam S, Blackburn A, Ellis D. "Door to mask time" in non-invasive ventilation for exacerbations of chronic obstructive pulmonary disease. Thorax 2006;61(Suppl II):P178

72 Watkins E, Wills A, Wedzicha JA, et al. The outcome of home non-invasive positive pressure ventilation in patients at the London Chest hospital. Thorax 2006:61(Suppl II):S149.

73 Mikelsons C, Muncey TK, Wedzicha JA. Chronic obstructive pulmonary disease patients' experience of using non-invasive ventilation at home: a case study approach. Thorax 2006;61(Suppl II):P182. 